\title{
Review on Tsunami Risk Reduction in Indonesia Based on Coastal and Settlement Typology
}

\author{
Djati Mardiatno, M. Ngainul Malawani, Despry Nur Annisa, and Dandun Wacano
}

Received: September 2016 / Accepted: February 2017 / Published online: December 2017

(๑) 2017 Faculty of Geography UGM and The Indonesian Geographers Association

\begin{abstract}
This research aims to identify various coastal and settlement typology as the basis to determine action plan for reducing tsunami risk. The action plan were issued by referring to priority level of tsunami management. Comparative analysis was applied through comparing different coastal and settlement typology at the selected coastal area, considering the tsunami risk zones determined by National Disaster Management Agency (BNPB). The results show that mitigation strategies can be distinguished in various coastal and settlement typology for each priority area, i.e. in Mentawai megathrust, Sunda Strait and the southern part of Java, Bali region and Nusa Tenggara, and Papua region. The components of action plan should be conducted in accordance with the priority level of each region.
\end{abstract}

Key words: tsunami risk, coastal profile, settlement typology, priority level, InaTEWS

\begin{abstract}
Abstrak Penelitian ini bertujuan untuk mengidentifikasi berbagai tipologi pesisir dan permukiman sebagai dasar untuk menentukan rencana aksi untuk mengurangi risiko tsunami. Rencana aksi dihasilkan dengan mengacu tingkat prioritas manajemen tsunami. Analisis perbandingan diterapkan dengan cara membandingkan tipologi pesisir dan tipologi permukiman pada daerah kepesisiran terpilih. Pemilihan daerah tersebut mempertimbangkan zona risiko tsunami yang telah ditentukan oleh Badan Nasional Penanggulangan Bencana (BNPB). Hasil penelitian menunjukkan bahwa strategi-strategi mitigasi dapat dibedakan pada setiap kawasan prioritas yang bervariasi tipologi pesisir dan tipologi permukimannya. Kawasan tersebut meliputi kawasan megathrust Mentawai, Selat Sunda dan bagian Selatan Pulau Jawa, wilayah Bali dan Nusa Tenggara, dan wilayah Papua. Komponen-komponen rencana aksi sebaiknya dilaksanakan dengan mempertimbangkan tingkat proritas pada masing-masing wilayah.
\end{abstract}

Kata kunci : risiko tsunami, profil kepesisiran, tipologi permukiman, tingkat prioritas, InaTEWS

\section{Introduction}

Tsunami is a series of long waves caused by displacement of plate tectonics or in general, it is a seaquake. Velocity of tsunami waves could reach 170 $\mathrm{km} / \mathrm{h}$, but when it reached the superficial velocity decreases but the wave height increases. Tsunami may take casualties, damage economic activity, as well as damage the ecosystem in coastal areas [UNESCO, 2011]. In other defenition, tsunami is a series of waves in a wave train, generated by sudden, vertical displacement of a column of water. This displacement can be due to seismic activity, explosive volcanism, a

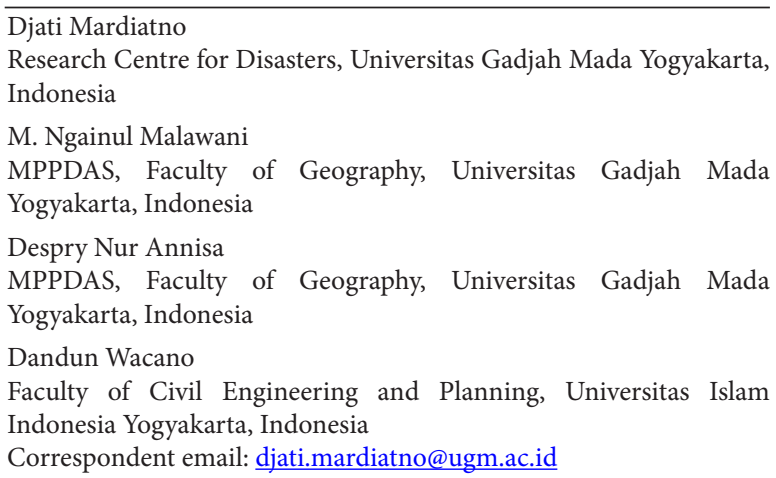

lanslide above or below water, an asteroid impact, or certain meteorological phenomena. [Bryant, 2008]

Indonesia has a long history hit by earthquakes and tsunamis. Indonesia is situated between oceanic plate and continental plate, which resulted in the reality that geologically, Indonesia is always disturbed by the plates displacement. The plates found here are the Eurasian Plate, the Pacific plate and Indo-Australian plate. Since the last two decades (1990-2010), there have been ten tsunami disaster events in Indonesia that destructed many infrastructures and cause casualties. The tsunami events were in Flores [1992] with 2.500 fatalities; Banyuwangi, 238 fatalities [1994]; Biak, 110 fatalities [1996]; Maluku, 18 fatalities [1998]; Banggai, 4 fatalities [2000]; Aceh, 165.000 fatalities [2004]; Nias, 800 fatalities [2005]; West Java, 200 fatalities [2006]; Bengkulu, 25 fatalities [2007]; and Mentawai, 413 inhabitants [2010]. During the past two decades, about 170.000 people died due to tsunami [BNPB, 2012]. According to the historical tsunami event in Indonesia, tsunami most casualties was happened in Aceh [December 2004].

Learning from these experiences, Indonesian Government decided to create Indonesian Tsunami 
Early Warning System (InaTEWS), initiated by the Coordinating Ministry for People's Welfare; Ministry of Research and Technology; Indonesian Agency for Meteorology, Climatology, and Geophysics (BMKG); Indonesian Agency for the Assessment and Application of Technology (BPPT), Indonesian Agency for Geospatial Information (BIG); and a variety of other relevant agencies, assisted by several friendly countries such as Germany, Australia, Japan, and the United States. InaTEWS has been inaugurated by the President on September $11^{\text {th }}, 2011$ with centered at BMKG. In addition to provide tsunami warnings in Indonesia, InaTEWS is also functioned as a source of tsunami information for countries located adjacent to the Indian Ocean coast. Following up InaTEWS system, the Indonesian Government at the same time also has launched a Temporary Evacuation Sites (TES) development program.

InaTEWS system requires engagement, attention, and commitment of institutions at various levels as well as the general public and residents of the coastal communities at risk. There are four elements used in this system, such as understand the hazard and risk, forecasting by monitoring data and warning services, dissemination of warnings from BMKG to populations at risk, and acting on warnings.

TES is a program of development and it is developed for a temporary evacuation. TES has nine activities as follows: (1) Strengthening the manufacture of evacuation planning in the area including the tsunami hazard map or tsunami risk map which more detailed (regency level), as the basic for evacuation maps; (2) Preparation of evacuation planning and evacuation maps are amplified with the general framework and policies in the region; (3) Development of tsunami evacuation nets; (4) Construction and development of tsunami TES; (5) Construction of paths and stairs evacuation; (6) Preparation of evacuation signs and warning boards; (7) Greenbelt for tsunami mitigation; (8) Preparation of an evacuation route map; (9) Socialization and dissemination of the TES. [BNPB, 2012].

InaTEWS system and TES program have already been implemented at the earthquake incident on April 11, 2012 in the western coast of Aceh. Viewed InaTEWS system elements and details of TES programs, efforts for disaster management by this system will be successful accordance with the target. But in the reality at the time, both efforts still have many weaknesses. Based on data from BNPB [2012], i.e. evaluation results from this disaster management system, there are three weaknesses as follows: (1) There is no clear division of roles between the local government and BMKG has made the people for evacuation; (2) The absence of guiding directions for evacuation so that most of people are still evacuating by using a vehicle and this causes congestion at the crossroads; and (3) Local people do not believe in supplying the building of TES so they prefer to evacuate themselves to upper land despite the distance that may be taken away. According to the weakness of the results from the InaTEWS and this TES program, it would require a new approach to make efforts for disaster mitigation in Indonesia.

BNPB has decided the priority areas with high risk to tsunami in Indonesia. All regions cover an area which has a coastline facing the plate collision zones or subduction zones. In general, the region can be divided into four regional zones, namely Megathrust Mentawai Zone, Sunda Strait and the Southern Sea of Java Zone, Bali and Nusa Tenggara Zone, and Northern Papua Zone.

Based on these conditions, the characteristics of coastal areas will have different response to tsunami. The larger cities such as Aceh, Padang, Banten, Yogyakarta, to Jayapura will have a different response to tsunami.

On the other hand, BNPB settled the cities which have a high risk zone to tsunami. Therefore, a specific approach is required to prepare mitigation plans in those areas. An alternative for that purpose is by utilizing coastal and settlement typology approach, because every region has a variety of coastal and settlements typology. Through this approach, it is expected to produce a mapping unit of tsunami risk and coastal areas profile to support the preparedness program for tsunami mitigation action plans. This idea is expected to support disaster risk reduction activities (Malawani and Mardiatno, 2015).

\section{The Methods}

Based on the earlier description, it is known that there are still weaknesses in the structure of tsunami disaster mitigation in Indonesia. It is necessary to create an alternative approach which is consistent with the characteristics of every region. Tsunami mitigation action plan is one of the plan management. Similar documents for that purpose is the National Action Plan for Disaster Risk Reduction (RAN-PRB) in a three-year time frame. This document explained that the RANPRB is the elaboration of National Disaster Management Plan (Renas PB) arranged to support policy formulation and monitoring in the implementation of disaster risk reduction activities [BAPPENAS and BNPB, 2012]. Framework used to create action plans through coastal and settlement typology approach is shown in Figure 1.

In determining the level of priorities and program initiation action plans, matrix calculation was applied for that purpose. Similar matrices can also be used to determine the threat level, the level of capacity, loss rate, and the level of risk [BNPB, 2011]. The matrix connects the two parameters and color difference indicates its level at every level. Coastal and settlements typology identification were conducted by using satellite images. After that, four parameter for determining priority level management can be assessed. Tools and materials used in this study are presented in Table 1. 


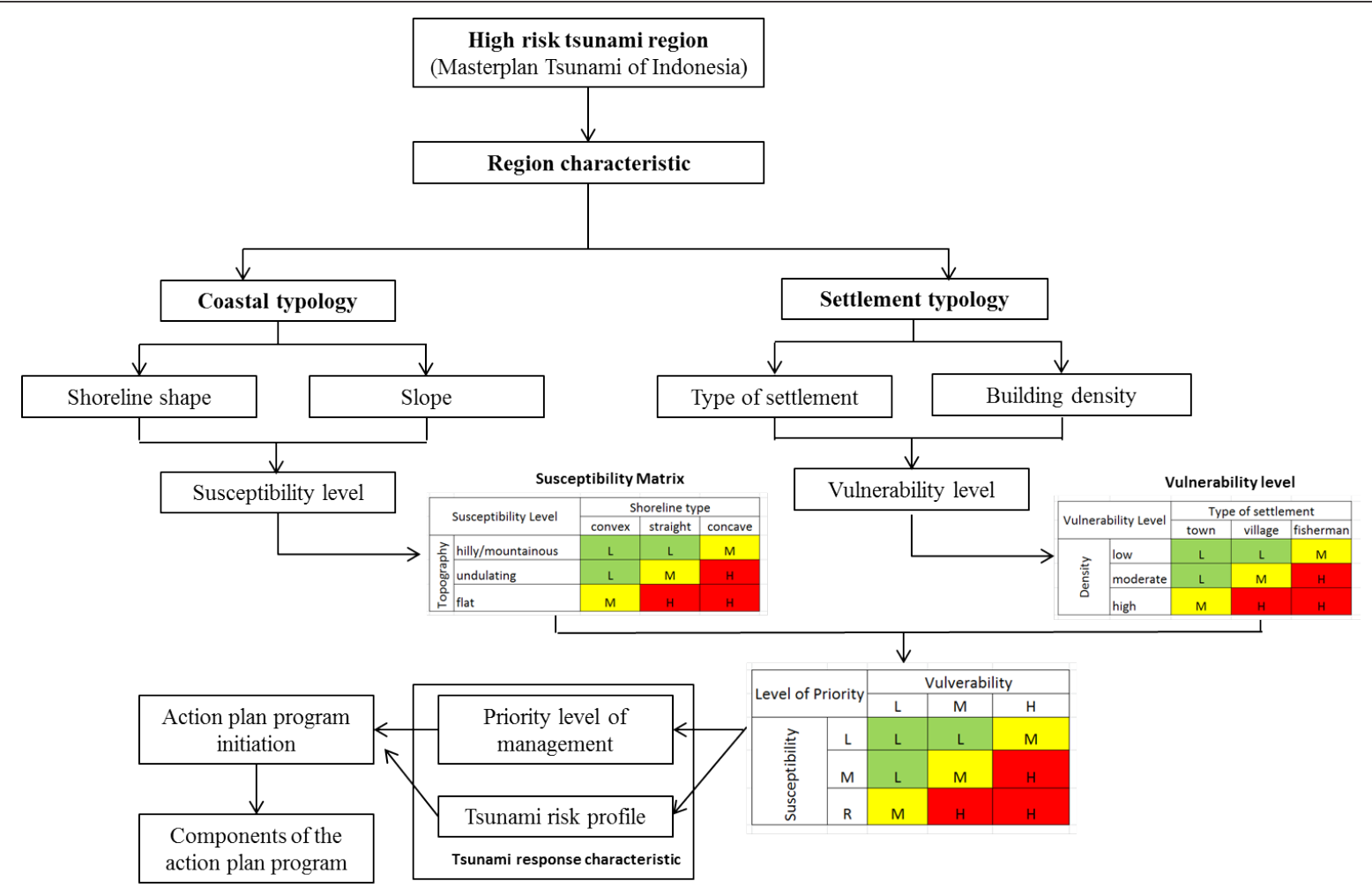

Figure 1. Research Framework

Table 1. Data and research materials

\begin{tabular}{ll}
\hline Data and Materials & Source \\
\hline Coastal typology & Satellite images \\
fopography/slope & Earth, Geoeye, \\
Beach shape & Landsat, SRTM \\
& Satellite images \\
Settlement typology & from Google \\
Building density & Earth, Geo-eye, \\
Type of building & field visit \\
Existence of disaster & Field visit, \\
mitigation program & literature study \\
Masterplan for Indonesian & \\
Tsunami Disaster & BNPB, 2012 \\
Reduction & \\
Sendai Framework for & \\
Disaster Risk Reduction & BNPB, 2015 \\
2015-2030 (Translation) & \\
\hline
\end{tabular}

\section{Results and Discussions}

National Agency for Disaster Management (BNPB) has determined a high risk of tsunami in Indonesia in Master Plan Tsunami of Indonesia 2012. Based on this document, Indonesia is divided into four areas of high risk tsunami, i.e. Mentawai megathrust, Sunda Strait and the southern part of Java, Bali region and Nusa Tenggara, also Papua region (Figure 2).
According to those areas, there are many people exposed to potential hazard of tsunami. More than 2,5 million people vulnerable to tsunami. The number of people exposed to tsunami can be seen in Table 2. Based on Dibyosaputro [2015], the residents usually prefer to live in the certain areas that potentially support their daily life. However, they sometimes do not care about the potential hazards occurrence since they only have limited options to select the location.

Under these conditions, there are challenges and opportunities on tsunami risk management in Indonesia. First challenge is: can tsunami risk management in Indonesia be run well in all regions? Many things that can be obstacles on the implementation of tsunami risk management in various region. Trouble may arise from the lack of preparedness or poor management that applied in various region. The characteristics of each region, both physical and anthropogenic factor can arise new challenge: is it able to apply the mitigation strategies according to the characteristics of each region? Study about tsunami mitigation plan in Indonesia become an interesting topic refer to all challenges mentioned before.

All challenges mentioned before give some opportunities to do. First opportunity is, tsunami risk management needs to be implemented according to the characteristics or profile of the region. In addition, keys of identification in mitigation strategies also need to be arranged into more detailed scale. It is very important, because tsunami risk mapping guide in Indonesia was 
directed in producing map at the district scale, i.e. 1:50.000 (see BNPB's Head Regulation No 2/2012). It will need further identification from standards that have been made for more detailed scale. This study provides an input to determine the mitigation strategies into detailed scale.

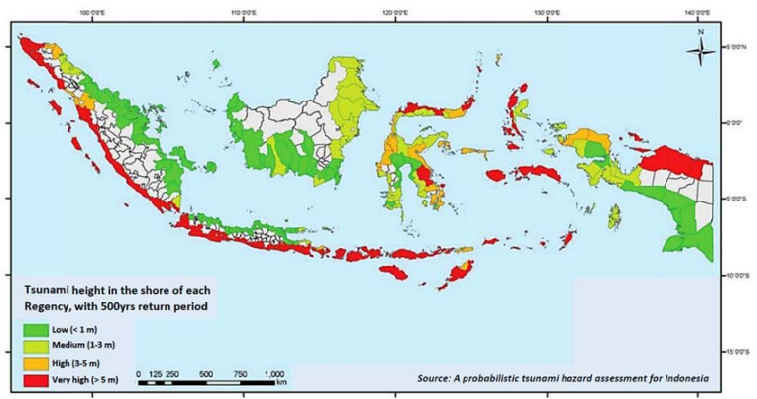

Figure 2. Potential Hazard of Tsunami Disaster in Indonesia [BNPB, 2012]

Triatmadja [2010] mentioned that tsunami disaster mitigation can be done by implementing two approaches, i.e. by physical and non-physical approach. Physical approach is similar to structural mitigation, while non-physical approach can be identical to non-structural mitigation. Both approaches would be different in each region. To distinguish that, it is necessary to propose an alternative method by creating new mapping unit. Based on the methodology previously mentioned, the function of mapping unit is to know the profile of the region based on coastal typology and settlement typology approach. To determine the mitigation strategies that fit to the region's profile, this method is applied at the several selected cities in tsunami high risk areas (Table 3).
According to Table 3 , it is known that several cities located in the high risk tsunami area in Indonesia have different coastal profile. This is an indication that tsunami risk management must be applied by different ways. In high priority level, surely the management must be better than in low priority level. Risk management can be detailed into action plan. Action plan consists of main component and derivative component that can be used as a work program. These components can be assembled from several sources such as the National Action Plan for National Disaster Risk Reduction and Sendai Framework for Disaster Reduction 2015-2030. The components and program of action plan can be seen in Table 4.

Based on the matrix component of the action plan (Table 4), it can be seen that each coastal area needs different plan of action. At the first priority level, all components of the action plan become mandatory and it is necessary to be finished in the short term. On the second priority, the development of science and technology does not become a fundamental things to be realized in the short term. It can also be found at the third priority area, where the development of tsunami evacuation is not essential to be established. It is caused by the fact that hazard and vulnerability are low in this priority. All components of the action plan presented in Table 4 are the main components which can be realized into mitigation action on each components. This approach is expected to be a new idea in the determination of the tsunami disaster mitigation actions at the local level in the high risk area to tsunami in Indonesia. It could be applied at the initial phase of tsunami risk analysis.

Table 2. Number of People Exposed in Priority Area of Tsunami Mitigation

\begin{tabular}{|c|c|c|c|}
\hline No & Priority area & Province & Nr. of people exposed \\
\hline \multirow[t]{3}{*}{1} & Megathrust Mentawai & North Sumatra & 106.601 \\
\hline & & West Sumatra & 298.203 \\
\hline & & Bengkulu & 98.246 \\
\hline \multirow[t]{6}{*}{2} & Sunda Strait and Southern part of Java & Lampung & 43.004 \\
\hline & & Banten & 346.381 \\
\hline & & West Java & 123.095 \\
\hline & & Middle Java & 943.497 \\
\hline & & DIY & 92.342 \\
\hline & & East Java & 194.649 \\
\hline \multirow[t]{3}{*}{3} & Bali and Nusa Tenggara & Bali & 358.905 \\
\hline & & West Nusa Tenggara & 119.138 \\
\hline & & East Nusa Tenggara & 31.823 \\
\hline \multirow[t]{3}{*}{4} & Papua region & West Papua & 14.092 \\
\hline & & Papua & 20.998 \\
\hline & Total & & 2.790 .974 \\
\hline
\end{tabular}

Source: BNPB, 2012 
Table 3. Identification of coastal profile in several cities on tsunami high risk area

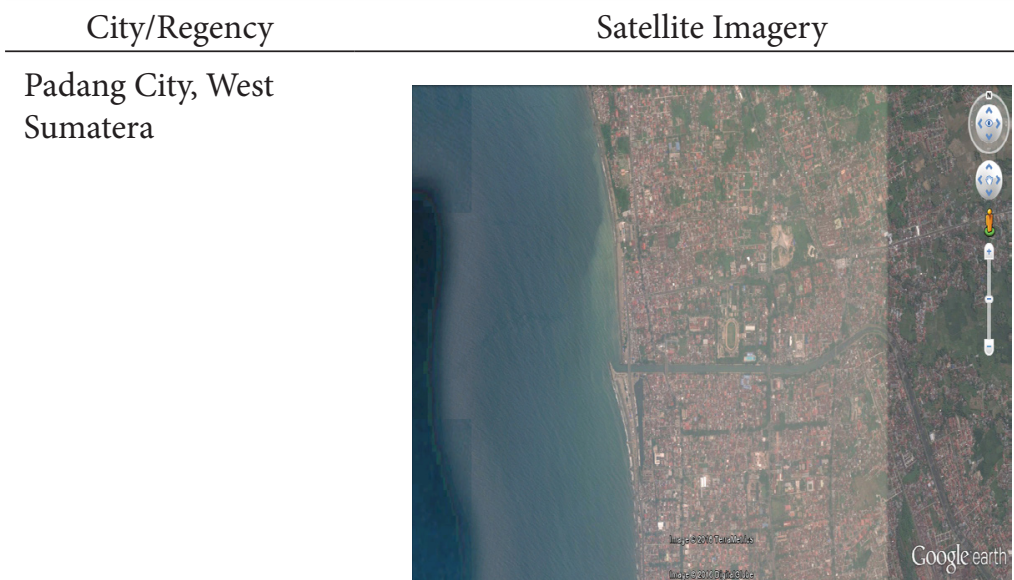

Nias Regency, North Sumatera

Bengkulu City, Bengkulu

Sukabumi, West Java
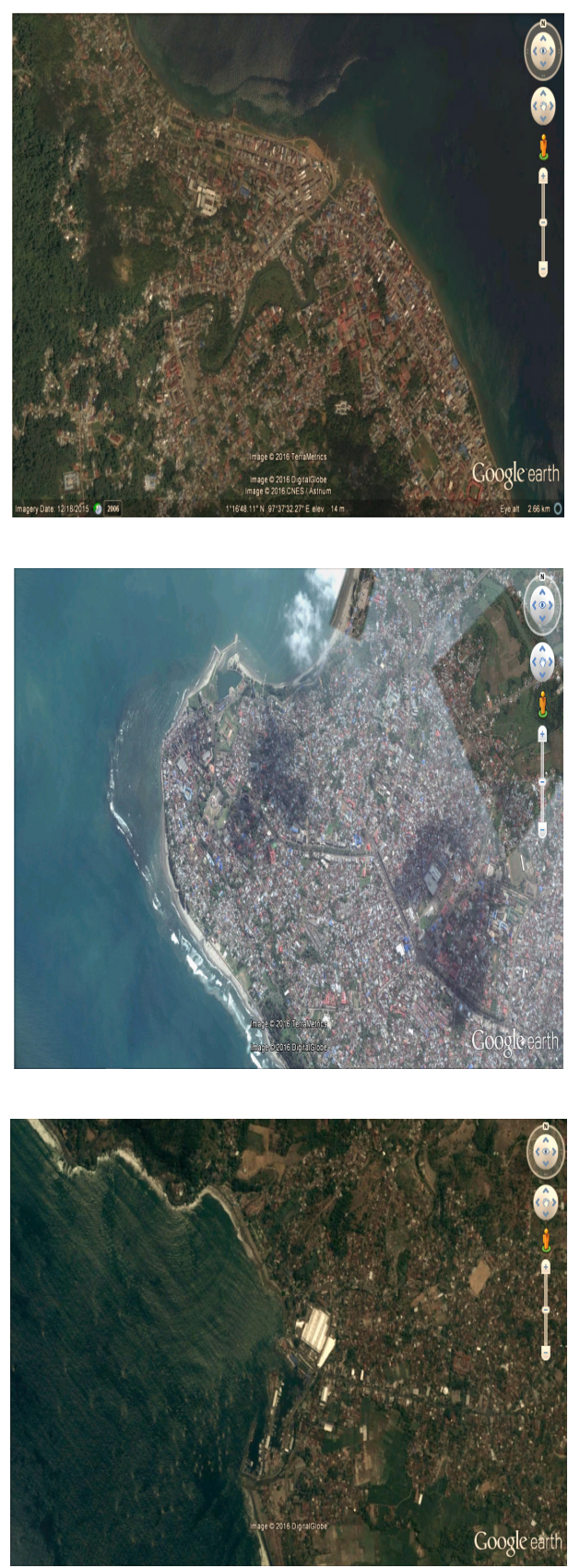

Coastal Profile

Shoreline shape : straight

Slope : flat

Building density : high

Settlement type : town

Susceptibility level : high

Vulnerability level : medium

Priority level : high

Shoreline shape : convex

Slope : undulating

Building density : medorate

Settlement type : village

Susceptibility level : low

Vulnerability level : medium

Priority level : low

Shoreline shape : convex

Slope : flat

Building density : high

Settlement type : town

Susceptibility level : medium

Vulnerability level : medium

Priority level : medium

Shoreline shape : concave

Slope : undulating

Building density : moderate

Settlement type : village

Susceptibility level : high

Vulnerability level : medium

Priority level : high 
Pacitan, East Java

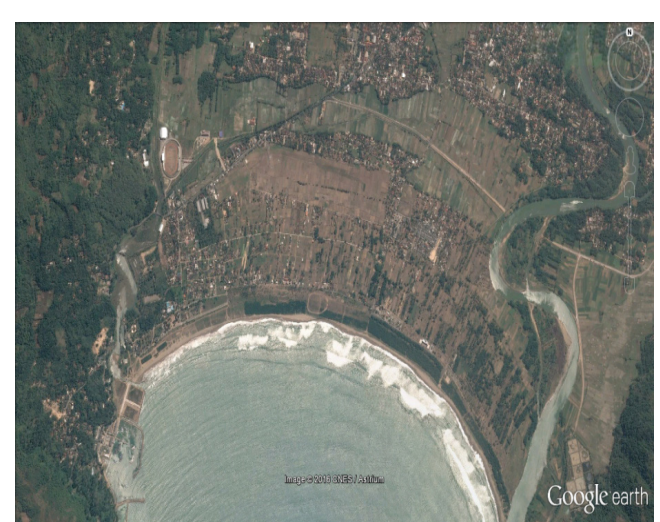

Denpasar, Bali

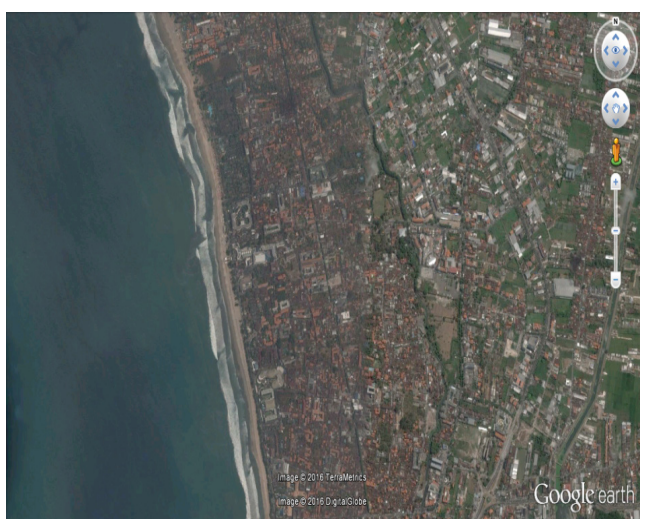

Sorong, West Papua

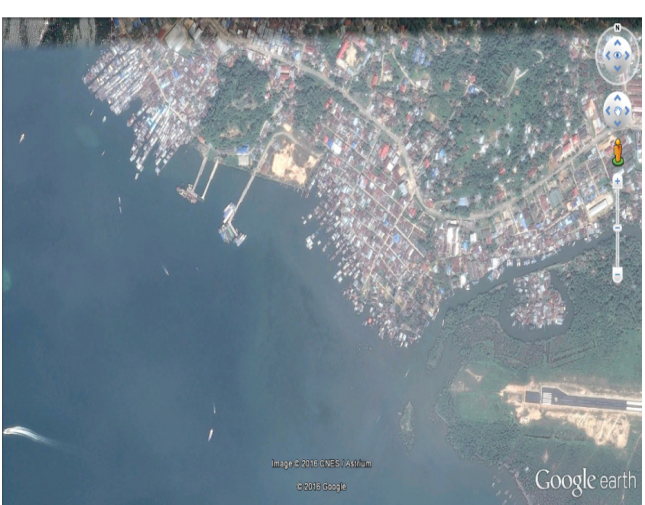

Jayapura, Papua

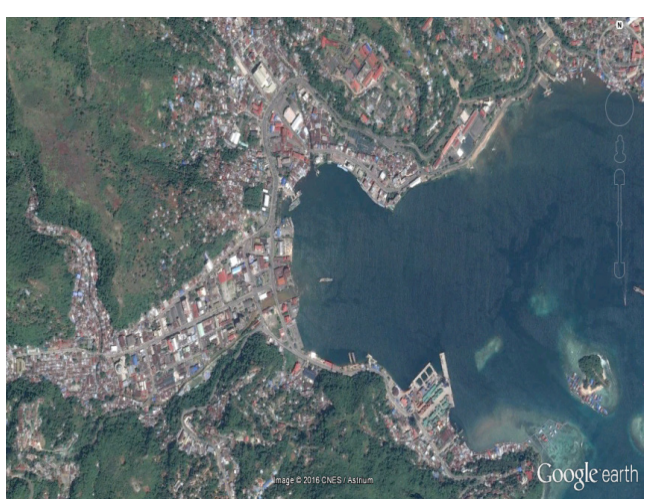

Shoreline shape : concave

Slope : flat

Building density : low

Settlement type : village

Susceptibility level : high

Vulnerability level : low

Priority level : medium

Shoreline shape : straight

Slope : flat

Building density : high

Settlement type : town

Susceptibility level : high

Vulnerability level : medium

Priority level : high

Shoreline shape : straight

Slope : flat

Building density : high

Settlement type : fisherman

Susceptibility level : high

Vulnerability level : high

Priority level : high

Shoreline shape : concave

Slope : undulating

Building density : high

Settlement type : town

Susceptibility level : high

Vulnerability level : medium

Priority level : high

Source: Interpretation based on Images from Gogle Earth and field visit 
Table 4. Components and programs of action plan on different coastal profile

\begin{tabular}{|c|c|c|c|}
\hline \multirow[b]{2}{*}{ Action plan component } & \multicolumn{3}{|c|}{ Coastal Profile } \\
\hline & $\begin{array}{l}\text { Priority level : } \\
\text { High }\end{array}$ & $\begin{array}{l}\text { Priority level : } \\
\text { Medium }\end{array}$ & $\begin{array}{l}\text { Priority level : } \\
\text { Low }\end{array}$ \\
\hline \multicolumn{4}{|l|}{$\begin{array}{l}\text { Improvement on Chain Systems of Tsunami Hazard } \\
\text { Early Warning System }\end{array}$} \\
\hline $\begin{array}{l}\text { Work program: } \\
\text { - The facilities and infrastructure improvements at } \\
\text { the site of the Tsunami Early Warning System Station }\end{array}$ & $\sqrt{ }$ & $\sqrt{ }$ & $\sqrt{ }$ \\
\hline \multicolumn{4}{|l|}{$\begin{array}{l}\text { - Preparation and Development of Information } \\
\text { boards of tsunami early warning }\end{array}$} \\
\hline \multicolumn{4}{|l|}{ Construction on Tsunami Evacuation Route and Site } \\
\hline \multicolumn{4}{|l|}{ Work program: } \\
\hline \multicolumn{4}{|l|}{ - Identification of tsunami evacuation route } \\
\hline $\begin{array}{l}\text { - Identify the location of Development Evacuation } \\
\text { Sites }\end{array}$ & & & \\
\hline - Maintenance on Tsunami Evacuation Sites & & & \\
\hline
\end{tabular}

Table 4. (Continued)

\begin{tabular}{|c|c|c|c|}
\hline \multirow[b]{2}{*}{ Action plan component } & \multicolumn{3}{|c|}{ Coastal Profile } \\
\hline & $\begin{array}{l}\text { Priority level : } \\
\text { High }\end{array}$ & $\begin{array}{l}\text { Priority level : } \\
\text { Medium }\end{array}$ & $\begin{array}{l}\text { Priority level } \\
\text { Low }\end{array}$ \\
\hline \multicolumn{4}{|l|}{$\begin{array}{l}\text { Increase Capacity and Tsunami Disaster } \\
\text { Preparedness }\end{array}$} \\
\hline \multicolumn{4}{|l|}{ Work program: } \\
\hline $\begin{array}{l}\text { - Disaster management training for government } \\
\text { officials (local government/municipal authorities) }\end{array}$ & $\sqrt{ }$ & $\sqrt{ }$ & $\sqrt{ }$ \\
\hline \multicolumn{4}{|l|}{$\begin{array}{l}\text { - Training on capacity of disaster preparedness } \\
\text { against groups with special needs (the disabled, the } \\
\text { poor, minorities, pregnant, children, etc.) }\end{array}$} \\
\hline \multicolumn{4}{|l|}{ Developing Science and Technology } \\
\hline \multicolumn{4}{|l|}{ Work program: } \\
\hline \multicolumn{4}{|l|}{$\begin{array}{l}\text { - Simulation and Modelling Study of Tsunami } \\
\text { - EWS technology development }\end{array}$} \\
\hline \multicolumn{4}{|l|}{$\begin{array}{l}\text { - Technology training and implementation at } \\
\text { national and local levels }\end{array}$} \\
\hline \multicolumn{4}{|l|}{ Reduction on Disaster Risk Factors } \\
\hline \multicolumn{4}{|l|}{ Work program: } \\
\hline - Vulnerability reduction of communities & $\sqrt{ }$ & $\sqrt{ }$ & $\sqrt{ }$ \\
\hline - Strengthening Institutional system & & & \\
\hline $\begin{array}{l}\text { - Building and environmental planning based on } \\
\text { coastal typology }\end{array}$ & & & \\
\hline
\end{tabular}

Source: Data analysis 
Tsunami risk assessment is an important component. Strunz et al. [2011] mentioned that tsunami hazard assessment must consider all possible scenarios for the basis in conducting risk assessment. GITEWS project resulted in overview scale of several thematic maps and GIS information layers in the sub national level for western Sumatra, south of Java, and Bali. That project also provided the detailed analysis scale in three pilot areas. However, it was issued before BNPB decided the Tsunami Masterplan for Indonesia in 2012, so that areas outside of GITEWS project are not covered. Based on Horspool et al. [2014], tsunami probability in the eastern part of Indonesia is like in the Sunda Arc part, so that more detailed tsunami risk analysis in the eastern part of Indonesia like in Moluccas, northern part of Papua and Sulawesi will be essential. According to this fact, it is very important to link the results from GITEWS and InaTEWS with Tsunami Masterplan produced by BNPB. Action plan components derived from coastal profile analysis are the efforts to synchronize both projects results.

Refer to Imamura et al. [2012], for tsunami mitigation plan, hazard information must consider the worst case scenario possibility, i.e. by estimating maximum inundation extent resulted from tsunami modelling. Regarding evacuation routes, the routes with high tsunami casualty index must be free from evacuation before tsunami comes. These also should be clear from overcrowding during the evacuation. In the flat area like in Padang city, it is necessary to integrate a comprehensive countermeasures for mitigating tsunami. It can also be implemented by using high building located inside the tsunami inundation area.

On the other hand, coastal materials should also be considered in mitigating coastal hazards such as tsunami. Mardiatno [2013] explained that coastal areas consist of sandy and muddy materials tend to have a high tsunami risk. Different mitigation treatment must be different for both areas, such as by planting different vegetation for each material to protect the coastal area from tsunami.

Coastal land use planning is also essential to minimize coastal hazards (e.g. tsunami) impact [Widianto and Damen, 2014]. It is a part of mitigation strategy for coastal area protection, which is very useful to preserve coastal resources and to safe people living in that location. Furthermore, the development of coastal forest as well as coastal belt boundary are also very important for tsunami mitigation [Mardiatno, 2013; Widianto and Damen, 2014]. It is a cheap alternative compared to hard construction development and often applied in many countries.

\section{Conclusions}

Priority level of tsunami management in Indonesia is varied in several cities. Priority level is composed from level of susceptibility and vulnerability. Priority level can be used to determine the action plan components. These components can be simplified into five action plans classification. They should be conducted in accordance with the priority level of each region. Coastal materials and land use planning should also be considered at implementing the action plan for each region.

\section{Acknowledgement}

The authors would like to thank to all assistants that supported field data collection. Many thanks is also given to Mr. Harfiyadi, S.Si., for all valuable supports.

\section{References}

BAPPENAS and BNPB (2010). Rencana Aksi Nasional Pengurangan Risiko Bencana Tahun 2010-2012, Badan Perencanaan dan Pembangunan Nasional dan Badan Nasional Penanggulangan Bencana, Jakarta. (in Bahasa Indonesia).

BNPB (2011). Pedoman Umum Pengkajian Risiko Bencana untuk Rencana Penanggulangan Bencana, Badan Nasional Penanggulangan Bencana, Jakarta. (in Bahasa Indonesia).

BNPB (2012). Masterplan Pengurangan Risiko Bencana Tsunami, Badan Nasional Penanggulangan Bencana, Jakarta. (in Bahasa Indonesia).

BNPB (2013). Indeks Risiko Bencana Indonesia, Badan Nasional Penanggulangan Bencana, Jakarta. (in Bahasa Indonesia).

BNPB(2015). Kerangka KerjaSendaiuntukPengurangan Risiko Bencana 2015-2030, (Translation), Platform Nasional PRB, Badan Nasional Penanggulangan Bencana, Jakarta. (in Bahasa Indonesia).

Bryant, E. (2008). Tsunami, The Underrated Hazard (2nd Edition), Praxis Publishing Ltd., Chichester, $\mathrm{UK}$.

Dibyosaputro, S. (2015). Landform Control on Settlement Distribution Pattern in Progo Delta, Indonesia, Indonesian Journal of Geography, 47(2), 187-193.

Horspool, N., Pranantyo, I., Griffin, J., Latief, H., Natawidjaja, D. H., Kongko, W., Cipta, A., Bustaman, B., Anugrah, S. D., and Thio, H. K. (2014). A probabilistic tsunami hazard assessment for Indonesia, Nat. Hazards Earth Syst. Sci., 14(11), 3105-3122, doi: 10.5194/nhess-14-3105-2014.

Imamura, F., Muhari, A., Mas, E., Pradono, M.H., Post, J., and Sugimoto, M. (2012). Tsunami Disaster Mitigation by Integrating Comprehensive Countermeasures in Padang City, Indonesia, Journal of Disaster Research, 7 (1), 48-64.

Malawani, M.N., and Mardiatno, D. (2015). Rencana aksi mitigasi bencana tsunami melalui pendekatan 
tipologi pesisir dan permukiman, kasus pesisir Jayapura, Proceedings on Simposium Nasional Mitigasi Bencana Tsunami 2015, TDMRCUniversitas Syiah Kuala, Banda Aceh.

Mardiatno, D. (2013). A proposal for tsunami mitigation by using coastal vegetations: some findings from southern coastal area of Central Java, Indonesia, Journal of Natural Resources and Development, 2013, 07, 85-95, doi: 10.5027/jnrd.v3i0.07.

Strunz, G., Post, J., Zosseder, K., Wegscheider, S., Mück, M., Riedlinger, T., Mehl, H., Dech, S., Birkmann, J., Gebert, N., Harjono, H., Anwar, H. Z., Sumaryono, Khomarudin, R. M., and Muhari, A. (2011). Tsunami risk assessment in Indonesia, Nat. Hazards Earth Syst. Sci., 11(1), 67-82, doi: 10.5194/nhess-11-67-2011.

Triatmadja, R. (2010). Tsunami, Kejadian, Penjalaran, Daya Rusak, dan Mitigasinya, Gadjah Mada University Press, Yogyakarta. (in Bahasa Indonesia).

UNESCO (2008). Tsunami Preparedness-Information Guide for Disaster Planners, IOC Manuals and Guides No. 49, Intergovernmental Oceanographic Commission of UNESCO, Paris.

UNESCO (2011). Reducing and managing the risk of tsunamis, IOC Manuals and Guides No. 57. Intergovernmental Oceanographic Commission of UNESCO, Paris.

Widianto, A. and Damen, M. (2014). Determination of Coastal Belt in Disaster Prone Area, Indonesian Journal of Geography, 46(2), 125-137. 